MaPan : Jurnal Matematika dan Pembelajaran

p-ISSN: 2354-6883 ; e-ISSN: 2581-172X

Volume 7 No 1, June 2019 (112-125)

DOI: https://doi.org/10.24252/mapan.2019v7n1a9

\title{
PROFIL FLEKSIBILITAS SISWA SD DALAM MEMECAHKAN MASALAH GEOMETRI DITINJAU DARI GENDER
}

\author{
Agus Subaidi'1), Harfin Lanya ${ }^{2)}$ \\ 1,2Universitas Madura \\ 1,2Jl. Raya Panglegur 3,5 KM, Pamekasan, Indonesia \\ Email: agus_math@unira.ac.id 1 ), lanya.harfin@gmail.com²)
}

Submitted:31-10-2018, Revised: 19-05-2019, Accepted: 27-06-2019

\begin{abstract}
Abstrak:
Penelitian ini bertujuan untuk mendeskripsikan profil fleksibilitas siswa SD dalam memecahkan masalah geometri. Metode penelitian yang digunakan adalah penelitian deskriptif eksploratif dengan pendekatan kualitatif. Teknik pengumpulan datanya dilakukan dengan pemberian tugas dan wawancara. Analisis data menggunakan metode triangulasi. Hasil penelitian yang diperoleh yakni subjek laki-laki menyebutkan informasi yang diketahui dan mengungkapkan pertanyaan dalam soal dengan tepat, dan dapat menyelesaikan masalah geometri dengan menggunakan lima cara, sedangkan subjek perempuan menyebutkan informasi yang diketahui dan mengungkapkan pertanyaan dalam soal dengan tepat dan dapat menyelesaikan masalah geometri dengan menggunakan tujuh cara.
\end{abstract}

Kata Kunci: Fleksibilitas, Pemecahan Masalah Geometri, Gender

\section{THE FLEXIBILITY PROFILE OF THE ELEMENTARY SCHOOL STUDENTS IN SOLVING THE GEOMETRY TESTS BASED ON THE GENDER}

\begin{abstract}
:
The study aimed at describing the flexibility profile of the elementary students in solving the geometry tests. The research method used in this study was explorative descriptive research with a qualitative approach. Giving assignments and the interview were used as the data collection technique. Furthermore, the data obtained used triangulation method. The findings showed that the male students mentioned the known information and answered the questions correctly, while the female students mentioned the known information and answered the questions correctly as well as able to solve the geometry tests by using seven ways.
\end{abstract}

Keywords: Flexibility, Problem Solving Geometry, Gender

How to Cite: Subaidi, A., \& Lanya, H. (2019). Profil fleksibilitas siswa SD dalam memecahkan masalah geometri ditinjau dari gender. MaPan : Jurnal Matematika dan Pembelajaran, 7(1), 112-125. 


\section{PENDAHULUAN}

Kemampuan berpikir kreatif perlu kiranya dikenali dan dikembangkan oleh guru melalui aktivitas-aktivitas kreatif dalam pembelajaran matematika. Kreatifitas dianggap sebagai hasil dari berpikir kreatif, sedangkan kegiatan dalam pembelajaran yang diarahkan untuk mendorong atau memunculkan kreatifitas siswa merupakan aktivitas kreatif. Kemampuan untuk melihat atau memikirkan hal-hal yang luar biasa, tidak lazim, memadukan informasi yang kelihatannya tidak berhubungan dan mencetuskan solusi-solusi baru atau gagasan-gagasan baru yang menunjukkan kefasihan, fleksibilitas, dan kebaruan dalam berpikir (Munandar, 2009).

(Silver, 1997) menggunakan pengajuan dan pemecahan masalah dalam menilai ketiga indikator kemampuan berpikir kreatif siswa. Ketiga indikator tersebut yaitu kefasihan, fleksibilitas, dan kebaruan. Menurutnya fleksibilitas dalam pemecahan masalah berhubungan dengan kemampuan siswa memecahkan masalah dalam beberapa cara.

Ketiga indikator tersebut meninjau hal yang berbeda, sehingga masingmasing siswa atau individu mempunyai kemampuan yang berbeda pula sesuai dengan pencapaian siswa dari ketiga indikator tersebut. Bisa saja terdapat siswa yang memenuhi ketiga indikator berpikir kreatif sekaligus, dua indikator atau satu indikator saja.

Dalam penelitian ini, penulis hanya memfokuskan pada satu indikator kreatifitas yaitu fleksibilitas. Hal ini disebabkan karena fleksibilitas merupakan kemampuan penting dalam menyelesaikan masalah yang harus dimiliki siswa (Pehkonen, 1997). Hal ini sesuai dengan Haylock dalam (Siswono, 2008) yang mengatakan bahwa kreatifitas sering melibatkan fleksibilitas. Bahkan Krutetskii (Siswono, 2008) mengidentifikasi bahwa fleksibilitas dari proses mental sebagai suatu elemen kunci kemampuan kreatif matematis siswa. Sehingga seseorang yang memiliki fleksibilitas rendah tidak mudah mengubah ide atau pandangan mereka meskipun ia mengetahui ide yang dimiliki kontradiksi dengan ide baru. Pendapat ini menegaskan eksistensi aspek fleksibilitas dalam kemampuan kreatif matematis. Selain alasan tersebut, aspek fleksibilitas dipilih karena aspek tersebut mudah untuk diungkap dari diri siswa yaitu dapat langsung diamati melalui hasil pekerjaan siswa dan pengungkapan ide mereka secara lisan.

Pada penelitian ini, pemecahan masalah menjadi alat untuk mengukur fleksibilitas siswa. Hal ini didasari (Pehkonen, 1997) menyatakan bahwa dengan pemecahan masalah dapat mendorong kreativitas sebagai produk berpikir 
kreatif siswa. Tetapi, itu bukan satu-satunya cara karena masih terdapat pendekatan lain salah satunya adalah pengajuan masalah.

Sering dijumpai siswa SD mengalami kesulitan dalam memecahkan masalah geometri. Penulis menilai yang menyebabkan kesulitan tersebut karena kurangnya pemahaman siswa tentang pengetahuan geometri sebelumnya yang menjadi pengetahuan prasyarat bagi siswa untuk mempelajari geometri selanjutnya. Sebagaimana pendapat Ausubel (Hudojo, 1988), bahwa pengetahuan sebelumnya berpengaruh terhadap pengetahuan baru yang akan dimiliki seseorang. Oleh karena itu, dari pendapat tersebut jelas bahwa pengetahuan sebelumnya akan sangat bermanfaat bagi siswa untuk mempelajari materi baru. Selain itu timbulnya kesulitan karena siswa kurang dilatih untuk memecahkan masalah geometri dengan berbagai macam cara/strategi. Sehingga pada saat siswa diberikan masalah baru yang berbeda dari contoh soal yang diberikan guru. Siswa tidak mampu memilih langkah yang tepat dalam pengerjaan, atau bahkan ketidaktahuan siswa tentang adanya langkah lain yang bisa digunakan dalam penyelesaian soal atau bisa dikatakan siswa tidak fleksibel.

Setiap siswa memiliki kemampuan yang berbeda-beda dalam memecahkan masalah, baik itu siswa laki-laki ataupun siswa perempuan. Hal ini sejalan dengan hasil penulisan (Zhu, 2007) mengenai perbedaan gender yang menyimpulkan bahwa laki-laki dan perempuan memiliki preferensi yang berbeda dalam penggunaan strategi pemecahan masalah. Benbow dan Stanley dalam (Orton, 1992) yang menyatakan bahwa jenis kelamin berpengaruh terhadap hasil belajar matematika. Kemampuan matematika laki-laki memang lebih baik dalam tugas-tugas spasial sehingga dalam topik matematika tertentu anak laki-laki memperoleh skor yang lebih tinggi dibandingkan perempuan seperti pecahan, geometri, dan masalah ilmu ukur ruang, sedangkan perempuan lebih baik pada kemampuan verbal. Brandon, P., Newton, B.J., and Hammond (1985) menyebutkan bahwa dalam pembelajaran matematika dipengaruhi gender khususnya pada usia sekolah dasar.

Menurut American Psychological Association dalam (Lestari, 2010) menyatakan bahwa kemampuan perempuan di seluruh dunia dalam matematika cukup baik dibandingkan dengan kemampuan laki-laki walaupun laki-laki memiliki kepercayaan diri yang lebih dari pada perempuan dalam matematika.

Berdasarkan hasil penelitian yang dipaparkan di atas menyatakan bahwa adanya variasi hasil penulisan mengenai peran gender dalam 
pembelajaran matematika. Beberapa hasil menyatakan adanya faktor gender dalam pembelajaran matematika, tetapi pada sisi lain dari beberapa penulisan mengungkapkan bahwa gender tidak cukup berpengaruh dalam pembelajaran matematika.

Berdasarkan latar belakang di atas, maka perlu untuk diketahui mengenai profil fleksibilitas seorang siswa SD dalam memecahkan masalah. Karena dengan begitu dapat dijadikan tambahan informasi tentang kemampuan fleksibilitas siswa dan untuk selanjutnya dapat menjadi bahan pertimbangan dalam merancang pembelajaran di kelas sehingga bisa memunculkan atau bahkan mengembangkan kemampuan fleksibilitas siswa. Besar manfaatnya bagi siswa yang kemampuan fleksibilitasnya baik dalam memecahkan masalah karena pada saat ujian mereka akan terampil dalam menjawab suatu masalah dengan memilih cara terbaik.

\section{METODE PENELITIAN}

Penelitian yang dilaksanakan ini merupakan penelitian deskriptif eksploratif dengan pendekatan kualitatif yang bertujuan untuk mendeskripsikan dan menggali profil fleksibilitas siswa laki-laki dan siswa perempuan SD dalam memecahkan masalah geometri. Subjek penelitian yang dipilih adalah siswa kelas 6 semester 2 SD Nurul Hikmah Pamekasan yang mempunyai kemampuan matematika tinggi yang relatif sama dan dapat berkomunikasi lisan maupun tulisan, dengan alasan siswa berkemampuan tinggi biasanya dapat memecahkan suatu masalah dan dapat pula dilihat kemampuan fleksibilitasnya. Peneliti menentukan subjek berdasarkan informasi dari guru dalam hal nilai hasil ujian mata pelajaran matematika pada semester sebelumnya dan kemampuan komunikasinya. Berdasarkan ketentuan tersebut maka terpilihlah dua subjek yaitu 1 siswa laki-laki dan 1 siswa perempuan.

Instrumen yang digunakan berupa tugas pemecahan masalah dan pedoman wawancara. Keduanya divalidasi sebelum digunakan. Selanjutnya, data yang diperoleh dari hasil penelitian, kemudian dianalisis dengan pendekatan kualitatif. Adapun tahapan dalam menganalisis meliputi reduksi data, penyajian data, dan penarikan kesimpulan.

Adapun Fleksibilitas menurut Jon, dkk (2007) merupakan komponen penting dari dalam pemahaman matematika, seorang pemecah masalah yang fleksibel tidak hanya tahu beberapa cara untuk menyelesaikan masalah, tetapi juga mengambil dan memilih di antara beberapa pendekatan yang diketahui, 
berdasarkan pengetahuannya yang memerlukan strategi bekerja terbaik pada masalah tertentu. Sedangkan menurut (Savelyeva, 2014) bahwa keluwesan (Flexibility) adalah kemampuan untuk mengemukakan bermacam-macam pemecahan atau pendekatan terhadap masalah. Berdasarkan beberapa pendapat di atas, maka dapat disimpulkan bahwa ciri utama fleksibilitas adalah mengetahui beberapa strategi. Pemecahan masalah dapat diselesaikan secara efisien dan efektif, serta dapat meyakinkan kebenaran terhadap jawaban yang diperoleh melalui beberapa cara yang sudah diterapkan apabila memiliki fleksibilitas dalam dirinya, artinya dapat menyelesaikan masalah dengan benar. Sehingga indikator yang digunakan dalam mengetahui profil fleksibilitas siswa SD dalam memecahkan masalah geometri pada penelitian ini dapat dilihat pada tabel 1 berikut:

Tabel 1. Indikator Fleksibilitas

\begin{tabular}{cl}
\hline Kemampuan yang Diukur & \multicolumn{1}{c}{ Indikator } \\
\hline Fleksibilitas & - Menggunakan lebih dari satu strategi/cara \\
& - Menyelesaikan masalah geometri dengan benar \\
& - Mengungkapkan cara yang paling efisien dan \\
& efektif dalam strategi/cara berdasarkan hasil yang \\
& diperoleh \\
\hline
\end{tabular}

\section{HASIL PENELITIAN DAN PEMBAHASAN}

Berdasarkan kriteria penentuan subjek yang sudah ditentukan, dipilih dua siswa sebagai subjek penelitian. Subjek yang pertama yaitu siswa laki-laki sebagai SL dan subjek kedua yaitu siswa perempuan sebagai SP. Berikut adalah hasil dan pembahasan tentang TPM dan wawancara yang telah peneliti dapatkan:

\section{Profil Fleksibilitas Siswa Laki-laki SD dalam Memecahkan Masalah Geometri}

Dalam indikator menggunakan lebih dari satu strategi/cara, SL menyebutkan informasi yang diketahui dan mengungkapkan pertanyaan dalam soal. Subjek menyelesaikan masalah geometri dengan menggunakan lima cara/strategi.

Dalam indikator, menyelesaikan masalah geometri dengan benar, SL menjelaskan dari lima cara yang digunakan dengan tepat dan benar. Cara pertama, subjek membagi bangun datar menjadi dua bagian yang sama yakni 
berbentuk trapesium siku-siku dengan menarik garis tengahnya. Kemudian menjumlahkan luas trapesium 1 dan 2. Perhatikan gambar 1 berikut:

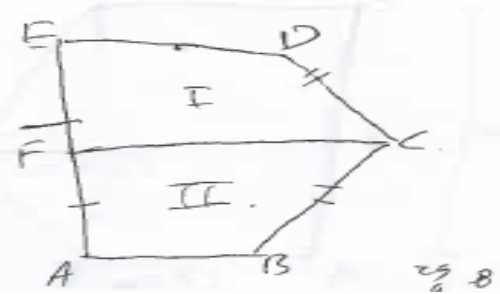

Gambar 1. Cara Pertama dalam Menyelesaikan Masalah Geometri

Sebagian penjelasan SL terkait cara pertama tersebut dapat diamati pada transkrip wawancara berikut:

PL: Coba adik jelaskan cara yang pertama, silakan!

SL: Luas trapesium, ini juga luas trapesium (sambil menunjukkan pada gambar).

PL: Ini trapesium apa?

SL: Trapesium siku-siku

PL: Berarti kamu bagi dua ya bangun datar ini?

SL: Ya.

Cara kedua, subjek menyampaikan bahwa kedua trapesium pada cara 1 kongruen sehingga untuk menentukan luas bangun datar tersebut cukup menghitung 1 luas trapesium kemudian hasilnya tinggal dikali dua. SL menjelaskan cara kedua tersebut seperti yang terlihat pada transkrip wawancara berikut:

PL: Kalau cara yang kedua? Silakan dijelaskan.

SL: Ini (sambil menunjuk pada gambar yang pertama) trapesium dikali 2

Cara ketiga, subjek membagi bangun datar menjadi dua bagian yakni persegi panjang dan segitiga. Kemudian luas bangun tersebut dijumlahkan. Perhatikan gambar 2 berikut:
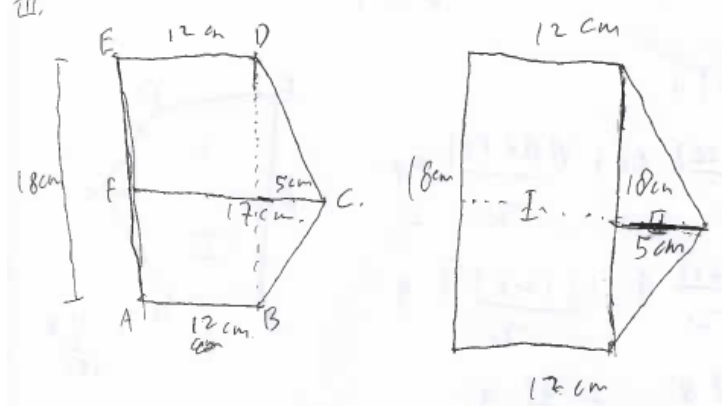

Gambar 2. Cara Ketiga dalam Menyelesaikan Masalah Geometri 
Sebagian penjelasan SL terkait cara ketiga tersebut dapat diamati pada transkrip wawancara berikut:

PL: Bagaimana dengan cara yang ketiga? Silakan dijelaskan!

SL: 12 di sini 12 di sini 18 (sambil menunjuk pada gambar). Supaya berbeda ditarik garis dari sini ke sini, jadi menentukan luasnya $=$ luas persegi panjang + luas segitiga $=$ luas persegi panjang $18 \times 12$.

Cara keempat, subjek awalnya membagi menjadi dua trapesium seperti pada cara pertama, akan tetapi agar supaya cara penyelesaiannya berbeda, maka pada salah satu trapesium, subjek menarik garis antara dua sudut yang berhadapan sehingga terbentuk dua segitiga. Dalam hal ini bangun datar itu dibagi menjadi 3 buah bangun datar. Kemudian subjek menghitung luas masing-masing bangun datar tersebut dan menjumlahkannya. Perhatikan gambar 3 berikut:

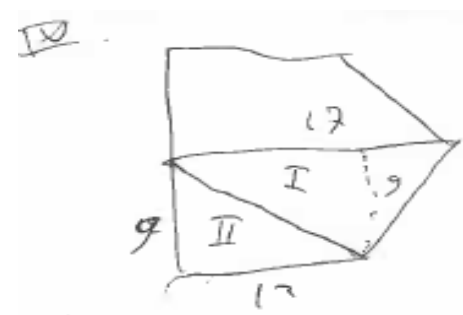

Gambar 3. Cara Keempat dalam Menyelesaikan Masalah Geometri

Sebagian penjelasan SL terkait cara 4 tersebut dapat diamati pada transkrip wawancara berikut:

PL: Selanjutnya cara yang keempat bagaimana?

SL: Ini supaya berbeda ditarik garis (sambil menunjuk pada gambar), terus ini dicari luasnya, ini dicari luasnya terus dikali 2, terus mencari luas yang pertama, ini mencari luas segitiga, tingginya 9 alasnya 17 .

Cara kelima subjek menjadikan bentuk bangun datar pada soal menjadi suatu bentuk persegi panjang dengan cara menambahkan garis putus-putus di luar bangun datar sehingga terlihat ada dua buah segitiga kecil yang sama. Subjek juga menjelaskan ukuran dari segitiga-segitiga kecil tersebut. Setelah itu subjek menghitung luas persegi panjang dan mengurangi dengan luas segitigasegitiga kecil. Perhatikan gambar 4 berikut: 


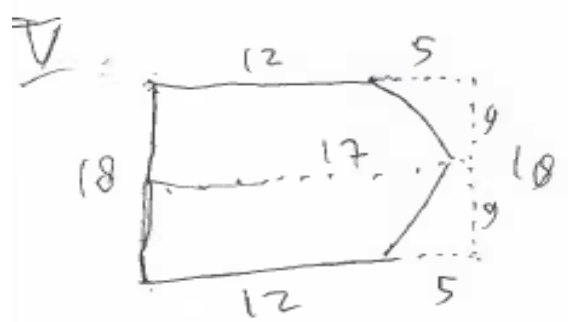

Gambar 4. Cara Kelima dalam Menyelesaikan Masalah Geometri

Sebagian penjelasan SL terkait cara kelima tersebut dapat diamati pada transkrip wawancara berikut:

PL: Ini kamu buat garis putus-putus untuk apa?

SL: Untuk agar jadi persegi panjang

PL: $\mathrm{Ooo}_{, \prime \prime}$, persegi panjang, berarti awalnya dibagi menjadi persegi panjang, setelah itu?

SL: Dikurangi segitiga yang kecil ini, jika sudah ketemu, segitiganya dikali 2.

Subjek juga menjelaskan dalam wawancara bahwa perbedaan dari ke lima cara yang digunakan yakni membagi gambar ke dalam beberapa bagian bangun datar atau menambahkan bangun datar baru untuk memudahkan dalam menyelesaikan. Kemudian menghitung jumlah luas bagian-bagian tersebut.

Dalam indikator mengungkapkan cara yang paling efisien dan efektif dalam strategi/cara berdasarkan hasil yang diperoleh, SL mengungkapkan cara yang paling efisien dan efektif dalam menyelesaikan masalah yaitu cara 2, menggunakan luas trapesium dikali 2.

\section{Profil Fleksibilitas Siswa Perempuan SD dalam Memecahkan Masalah Geometri}

Dalam indikator menggunakan lebih dari satu strategi/cara, SP menyebutkan apa yang diketahui dan ditanyakan berdasarkan apa yang diketahui sisi $\mathrm{AB}=\mathrm{BD}$ itu panjangnya 12, garis $\mathrm{FC}$ itu panjangnya $17 \mathrm{~cm}$, EA panjangnya $18 \mathrm{~cm}$. Sedangkan yang ditanyakan adalah luas bangun datar. Subjek mengerjakan dengan tujuh cara dalam menyelesaikan soal geometri.

Dalam indikator menyelesaikan masalah geometri dengan benar, SP menjelaskan tujuh cara yang digunakan dalam memecahkan masalah geometri 
dengan tepat dan benar. Sebagian penjelasan SL terkait hal tersebut dapat diamati pada transkrip wawancara berikut:

PP: Ada berapa cara yang kamu gunakan?

SP: Ada tujuh.

PP: Ada tujuh cara. Oke, Apakah adik yakin bahwa cara satu dengan yang lain, semua cara yang adik gunakan itu memiliki jawaban yang sama?

SP: Iya sama semua.

SP dalam menyelesaikan masalah hanya melalui satu gambar saja. Ke tujuh cara yang digunakan tidak disertai gambar kembali pada setiap cara. Jadi hanya membuat garis-garis baru pada gambar yang ada di soal. Perhatikan gambar 5 berikut:

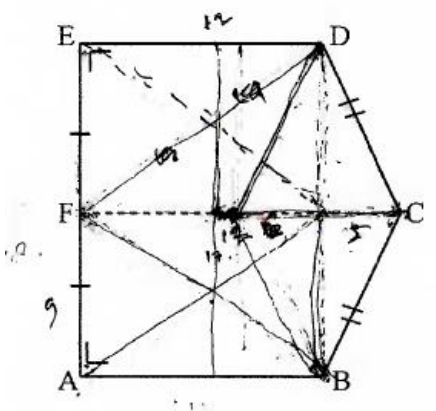

Gambar 5. Cara Subjek Perempuan Membagi Bangun Datar

Berikut ini merupakan penjelasan peneliti dari deskripsi hasil tugas sekaligus hasil wawancara pada subjek SP dalam menyelesaikan permasalahan. Cara 1 subjek membagi bangun datar menjadi 2 bagian, dengan membuat garis antara titik $\mathrm{F}$ dan titik $\mathrm{C}$ yaitu dua trapesium siku-siku yang kongruen yaitu ABCF dan EDCF. Kemudian subjek menjumlahkan luas 1 dan luas 2 bangun trapesium tersebut. Cara 2 subjek membagi bangun datar menjadi dua bagian, dengan membuat garis antara titik $B$ dan titik $D$ yaitu persegi panjang ABDE dan segitiga BCD. Kemudian menghitung luasnya dan menjumlahkan. Cara 3 subjek membagi bangun datar menjadi enam bagian segitiga. Subjek menambahkan titik baru antara titik $\mathrm{F}$ dan titik C. Titik tersebut berada di tengah-tengah antara garis $\mathrm{BD}$. Sehingga melalui titik baru tersebut dibentuk suatu garis baru dengan menarik titik F, E, D, C, B, dan A. Kemudian bangunbangun segitiga yang terbentuk tersebut dihitunglah luasnya dan dijumlahkan. Cara 4 subjek membagi bangun datar menjadi tiga bagian yaitu dari persegi ABDE dibagi menjadi dua bagian persegi panjang baru yang kongruen dan 
segitiga BCD. Kemudian dihitung luasnya masing-masing dan menjumlahkan. Cara kelima, subjek membagi bangun datar menjadi empat bagian segitiga yaitu segitiga AFB, FED, FDB, DBC. Kemudian keempat segitiga tersebut dihitung luasnya dan dijumlahkan. Cara 6 subjek membagi bangun datar menjadi 3 bagian yaitu dua trapesium siku-siku dan belah ketupat. Subjek mengambil titik F pada garis FC. Kemudian menarik garis dari D dan B ke titik tersebut sehingga terbentuk 3 bagian bangun tersebut. Subjek menghitung luas dari masing-masing bangun tersebut dan menjumlahkannya. Cara 7 subjek membagi bangun datar menjadi 3 bagian yaitu persegi panjang dan dua trapesium siku-siku. Melalui titik tengah $\mathrm{AB}$ dan $\mathrm{ED}$ ditarik suatu garis sehingga terbentuk suatu persegi panjang dan bangun satunya lagi di sebelah kanannya dibagi menjadi dua trapesium siku-siku dengan menarik garis tengah melalui titik $\mathrm{C}$ dan titik tengah garis baru yang ditarik sebelumnya. Kemudian subjek menghitung luas ketiga bangun tersebut dan menjumlahkannya. Subjek menjelaskan perbedaan dari ke tujuh cara yaitu terletak pada cara membagi bangun datar ke dalam beberapa bagian.

Dalam indikator mengungkapkan cara yang paling efisien dan efektif dalam strategi/cara berdasarkan hasil yang diperoleh, SP mengungkapkan cara yang paling efektif dan efisien dalam memecahkan masalah yaitu cara yang kedua. Gambar bangun datarnya dibagi menjadi dua bagian yaitu persegi panjang dan segitiga.

Berdasarkan uraian di atas, dalam profil fleksibilitas siswa laki-laki dan perempuan dalam memecahkan masalah geometri memiliki persamaan dan perbedaan. Hal itu dapat dilihat pada tabel 2 berikut.

Tabel 2. Persamaan dan Perbedaan Profil Fleksibilitas Siswa Laki-laki dan Perempuan dalam Memecahkan Masalah Geometri

\begin{tabular}{|c|c|c|c|}
\hline $\begin{array}{c}\text { Indikator } \\
\text { Fleksibilitas }\end{array}$ & Subjek & Persamaan & Perbedaan \\
\hline $\begin{array}{l}\text { Menggunakan } \\
\text { lebih dari satu } \\
\text { strategi/cara }\end{array}$ & $\begin{array}{l}\text { Siswa Laki- } \\
\text { laki }\end{array}$ & $\begin{array}{l}\text { - Lebih dari } \\
\text { satu } \\
\text { strategi/cara } \\
\text { - Terdapat cara } \\
\text { yang sama }\end{array}$ & $\begin{array}{ll}\text { - } & 5 \text { cara } \\
\text { - } & \text { Ide menyelesaikan } \\
\text { dengan } \\
\text { menambahkan garis } \\
\text { baru di dalam atau di } \\
\text { luar bangun datar } \\
\text { yang semula }\end{array}$ \\
\hline
\end{tabular}




\begin{tabular}{|c|c|c|}
\hline & $\begin{array}{l}\text { Siswa } \\
\text { Perempuan }\end{array}$ & $\begin{array}{l}\text { - } 7 \text { cara } \\
\text { - } \quad \text { Ide menyelesaikan } \\
\text { dengan selalu } \\
\text { menambahkan garis } \\
\text { baru di dalam } \\
\text { bangun datar yang } \\
\text { semula }\end{array}$ \\
\hline \multirow[t]{2}{*}{$\begin{array}{l}\text { Menyelesaikan } \\
\text { masalah geometri } \\
\text { dengan benar }\end{array}$} & $\begin{array}{l}\text { Siswa Laki- Jawaban Benar } \\
\text { laki }\end{array}$ & $\begin{array}{l}\text { Menggambar kembali } \\
\text { dan membagi gambar ke } \\
\text { dalam beberapa bagian } \\
\text { pada ke lima cara yang } \\
\text { digunakan }\end{array}$ \\
\hline & $\begin{array}{l}\text { Siswa } \\
\text { Perempuan }\end{array}$ & $\begin{array}{l}\text { Ke tujuh cara yang } \\
\text { digunakan tidak disertai } \\
\text { gambar kembali pada } \\
\text { setiap cara. Jadi hanya } \\
\text { membuat garis-garis } \\
\text { baru pada gambar yang } \\
\text { ada di soal }\end{array}$ \\
\hline $\begin{array}{l}\text { Mengungkapkan } \\
\text { cara yang paling } \\
\text { efisien dan efektif } \\
\text { dalam }\end{array}$ & $\begin{array}{l}\text { Siswa Laki- } \\
\text { laki }\end{array}$ & $\begin{array}{lr}\text { Membagi bangun datar } \\
\text { menjadi } 2 \text { bangun datar } \\
\text { trapesium } & \text { yang } \\
\text { kongruen. } & \end{array}$ \\
\hline $\begin{array}{l}\text { strategi/cara } \\
\text { berdasarkan hasil } \\
\text { yang diperoleh }\end{array}$ & $\begin{array}{l}\text { Siswa } \\
\text { Perempuan }\end{array}$ & $\begin{array}{l}\text { Gambar bangun datar } \\
\text { dibagi menjadi persegi } \\
\text { panjang dan segitiga. }\end{array}$ \\
\hline
\end{tabular}

Berdasarkan tabel di atas, dalam indikator menggunakan lebih dari satu strategi/cara. SL dan SP sama-sama menyebutkan informasi yang diketahui dan mengungkapkan pertanyaan dalam soal dengan tepat. Hanya saja SL menggunakan lima cara/strategi, sedangkan SP menggunakan tujuh cara dalam menyelesaikan soal geometri. Meskipun demikian, ke dua subjek bisa dikatakan memiliki kemampuan fleksibel. Sesuai yang disampaikan (Siswono, 2008) bahwa peserta didik yang seperti itu menunjukkan adanya fleksibilitas yakni terdapat banyaknya ide-ide berbeda yang digunakan.

Dalam indikator menyelesaikan masalah geometri dengan benar. Ke dua subjek menyelesaikan dan menjelaskan jawaban mereka dengan tepat dan benar. Hanya saja dari ke dua subjek memiliki perbedaan dalam teknik menyelesaikannya. Pada subjek laki-laki menggambar kembali bangun datar 
seperti pada soal. Kemudian dari gambar tersebut SL membagi bangun datar menjadi beberapa bagian. Hal itu dilakukan pada ke lima cara yang ditulis. Kemudian SL mencari luas bagian-bagian bangun datar tersebut, kemudian menjumlahkannya sehingga menemukan luas bangun datar yang dimaksud. Sedangkan SP dalam menemukan jawaban dari ke tujuh cara yang digunakan. Pada setiap caranya, SP membagi bangun datar tersebut menjadi beberapa bagian dengan mencoret-coret bangun datar pada soal. Kemudian menghitung luas bagian-bagian yang dicoret tersebut dan menjumlahkannya. Jawaban dan penjelasan SP lebih lengkap dan lancar dari SL.

Sedangkan persamaan subjek dalam cara yang digunakan SL dan SP yaitu 1) membagi gambar bangun datar menjadi dua trapesium yang kongruen, kemudian menghitung luas masing-masing trapesium dan menjumlahkannya, 2) membagi gambar bangun datar menjadi persegi panjang dan segitiga sama kaki, kemudian menghitung luas masing-masing trapesium dan menjumlahkannya. Namun dari cara kedua subjek ada keunikan tersendiri. Pada subjek laki-laki memiliki satu cara yang berbeda sekali dengan subjek perempuan yaitu subjek menambahkan garis bantu tidak hanya melalui di dalam bangun datar melainkan di luar bangun datar sehingga terbentuk persegi panjang. Sehingga subjek dalam mencari luasnya mengurangi luas persegi panjang dengan kedua segitiga baru yang diperoleh dari penambahan garis di luar bangun datar tersebut. Sedangkan pada subjek perempuan hanya melakukan penambahan garis di dalam bangun datar untuk membaginya. Hal ini dapat disimpulkan bahwa sebenarnya laki-laki memiliki kemampuan spasial yang berbeda dengan perempuan. Dalam hal ini, pemecahan masalah geometri subjek laki-laki dan subjek perempuan, menunjukkan perbedaan yaitu subjek laki-laki lebih unggul dalam melakukan visual spasial dan subjek perempuan lebih teliti, lebih cermat dan lebih seksama.

Dalam indikator mengungkapkan cara yang paling efisien dan efektif dalam strategi/cara berdasarkan hasil yang diperoleh. SL mengungkapkan cara yang paling efisien dan efektif dalam menyelesaikan masalah yaitu cara pertama, menggunakan luas trapesium dikali 2, sedangkan SP mengungkapkan cara yang paling efektif dan efisien dalam memecahkan masalah yaitu cara yang kedua. Gambar bangun datarnya dibagi menjadi dua bagian yaitu persegi panjang dan segitiga. 


\section{SIMPULAN}

Berdasarkan hasil analisis data penelitian dan pembahasan maka dapat ditarik kesimpulan bahwa profil fleksibilitas siswa SD dalam memecahkan masalah geometri berdasarkan gender memiliki persamaan dan perbedaan. Siswa laki-laki dan siswa perempuan dapat menyelesaikan masalah dengan menggunakan lebih dari 2 cara yang jawabannya sama-sama benar, siswa lakilaki menggunakan 5 cara sedangkan siswa perempuan 7 cara. Pada siswa lakilaki maupun perempuan memiliki cara yang berbeda dalam menyelesaikan masalah geometri.

\section{DAFTAR PUSTAKA}

Brandon, P., Newton, B.J., and Hammond, O. W. (1985). The superiority of girls over boysin mathematics achievment in hawaii. In Paper presented at annual meetingof American Educational Research Association. Retrieved from https:/ / eric.ed.gov/?id=ED260906

Hudojo, H. (1988). Mengajar belajar matematika. Jakarta: Departemen Pendidikan dan Kebudayaan Direktorat Jenderal Pendidikan Tinggi Proyek Pengembangan Lembaga Pendidikan Tenaga Kependidikan.

Lestari, N. D. F. (2010). Profil pemecahan masalah matematika open-ended siswa kelas $V$ Sekolah Dasar ditinjau dari perbedaan gender dan kemampuan matematika. Surabaya: UNESA.

Munandar, U. (2009). Pengembangan kreatifitas anak berbakat. Jakarta: Rineka Cipta.

Orton, A. (1992). Learning mathematics, issue, theory and classroom practise (3rd ed.). Trow bridge. Wilts.: Geat Britain, Printed, and Bound by Potesios Ltd.

Pehkonen, E. (1997). The State of art in mathematical creativity. ZDM Mathematic Education, 29(3), 63-67. Retrieved from https:/ / link.springer.com/article/10.1007/s11858-997-0001-z

R. Star, Jon \& Durkin, Kelley \& Rittle-Johnson, Bethany \& Lynch, Kathleen \& Newton, Kristie \& Gogolen, C. (2007). Improving students' flexibility in algebra: the benefits of comparison. Retrieved from https:/ / www.google.com/url?sa=t\&rct=j\&q=\&esrc=s\&source=web\&cd= 1\&ved=2ahUKEwjEkITu9YjjAhUMK48KHTTpDDMQFjAAegQIARAC\&u rl=http $\% 3 \mathrm{~A} \% 2 \mathrm{~F} \% 2 \mathrm{Fgseacademic}$.harvard.edu $\% 2 \mathrm{~F} \sim$ starjo $\% 2 \mathrm{Fpapers} \% 2 \mathrm{FC}$ alifAlgForum.ppt\&usg=AOvVaw27NHYuPcxjgBxEX_B9ddiZ

Silver, E. A. (1997). Fostering creativity through instruction rich in mathematical problem solving and thinkingin problem posing. ZDM Mathematic Education, 29(3), 75-80. Retrieved from https:/ /link.springer.com/article/10.1007/s11858-997-0003-x

Siswono, T. Y. E. (2008). Model pembelajaran matematika berbasis pengajuan dan pemecahan masalah untuk meningkatkan kemampuan berpikir kreatif. Surabaya: 
Unesa University Press.

Tamara Savelyeva. (2014). Implementation of creative education policy in russian higher education curricula. Creative Education, 5(2), 444-454. Retrieved from https:/ / www.scirp.org/(S(lz5mqp453edsnp55rrgjct55))/reference/ Refere ncesPapers.aspx?ReferenceID $=1088611$

Zhu, Z. (2007). Gender differences in mathematical problem solving. International Education Journal, 8(2). Retrieved from https://www.researchgate.net/publication/255607421_Gender_differenc es_in_mathematical_problem_solving_patterns_A_review_of_literature 